\title{
Managerial Optimism Level, Board of Directors Efficiency and Debt Decision in Tunisian Companies
}

\section{Mohamed Ali Azouzi}

Doctor, HDR and Assistant Professor in Finance and Accounting Methods, Faculty of Management, University of Monastir Sidi Messaoud, Mahdia, Tunisia.

Email:Mohamed_azouzi@yahoo.fr

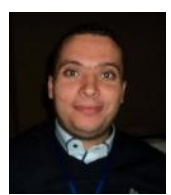

\begin{abstract}
This article deals with the relationship existing between the emotional aspect and decisionmaking processes. More specifically, it examines the links between managerial optimism level, debt decision and board of director's efficiency. This Stream of research argues that the CEO optimism level is affected by the Board of Directors efficiency. In this regard, an empirical study was conducted using a questionnaire as a data collection method adapted to a sample of 75 Tunisian firms. Regarding, The optimism level they have been measured by means of a questionnaire comprising several items. Our analyzes revealed the importance of CEO optimism in the debt decision. It has been found that an optimistic leader prefers more debt even in companies ruled by independent boards. On the other hand, the results' analyzing the hypotheses 2 and 3 regarding the size of the board and the combination of CEO and Board Chair does not confirm our theoretical analysis.
\end{abstract}

Keywords: CEO optimism, CEO education, Board of directors, Duality, Financial policy, Debt level, Behavioral corporate finance. JEL Classification: D2, G3, L2, L5, M1

Citation | Mohamed Ali Azouzi (2019). Managerial Optimism Level, Board of Directors Efficiency and Debt Decision in Tunisian Companies. Economy, 6(2): 82-91.

History:

Received: 2 October 2019

Revised: 5 November 2019

Accepted: 9 December 2019

Published: 17 January 2020

Licensed: This work is licensed under a Creative Commons

Attribution 3.0 License (cc) Ev

Publisher: Asian Online Journal Publishing Group
Funding: This study received no specific financial support.

Competing Interests: The author declares that there are no conflicts of interests regarding the publication of this paper.

Transparency: The author confirms that the manuscript is an honest, accurate, and transparent account of the study was reported; that no vital features of the study have been omitted; and that any discrepancies from the features of the study have been omit
study as planned have been explained.

study as planned have been explained.
Ethical: This study follows all ethical practices during writing.

\section{Contents}

1. Introduction. 83

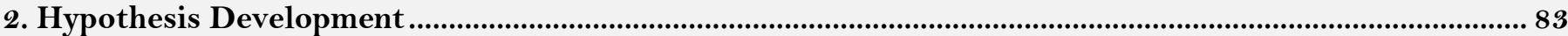

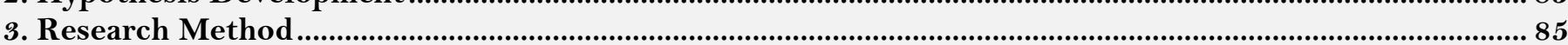

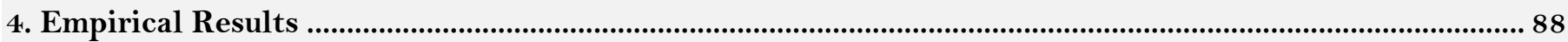

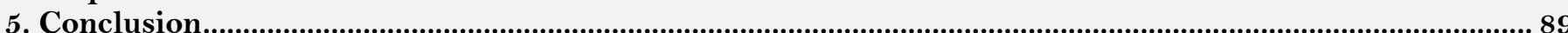

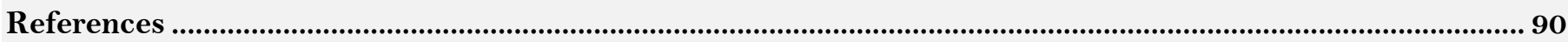




\section{Contribution of this paper to the literature}

In fact, to improve the explanatory power of the legal-financial approach to governance, the behavioral dimension has been integrated for a more in-depth analysis of the role of the board of directors. This study aims to highlight the role played by manager optimism on board effectiveness in controlling the company's debt level.

\section{Introduction}

Since the works of Modigliani and Miller (1958) which prove the irrelevance of financing decisions of companies under the conditions of the perfect market. A large number of theoretical and empirical analyzes have been developed to study the determinants of business financing decisions caused by various market imperfections in the real world. Earlier researchers in this field generally follow two competing theories, 'Static Trade off theory' and 'pecking order theory' which assumes a wide rationality. The study by Frank and Goyal (2003) concludes that there is no universal theory that can fully explain business financing decisions while traditional explanations for capital structure are largely based on the assumption of rationality of the managers.

Theorists integrated the behavioral dimension into the analysis of the choice of the capital structure; they explain his choice on the CEO emotional biases. This integration has enriched theories of capital structure: the Static Trade Off and Peking Order Theory (Azouzi and Jarboui, 2012; Azouzi and Jarboui, 2018). Some studies address the issue from the point of view that rational managers interact with rational outside investors too. Only recently a more small number of analyses emerging by focusing on cognitive biases (optimism, excess of trust and loss aversion) managers themselves and trying to understand how they can interact with the different statuses of the company and primarily with the control system.

Schrand and Zechman (2010) show that overly confident managers make optimistic forecasts and in order to meet these expectations, they show higher levels of future earnings. In a series of studies, Malmendier and Tate (2005); Malmendier and Tate (2008); Malmendier and Tate (2015) and Malmendier et al. (2010) formalize the notion of leadership behavior and provide empirical evidence to analyze the effects of managerial optimism level on funding preferences and capital structure choice.

The implications of optimism for the company's funding decisions have recently begun to be explored by behavioral finance researchers. In the psychological and behavioral literature, optimism is generally associated with an exaggerated positive perception about the probability that the favorable events will occur and simultaneously with the underestimation of the probability that the adverse events will occur. Similarly, Heaton (2002) argues that managers tend to overstate not only their investment opportunities but also the value of their companies. This principle gives a total convergence of the interests of direct with the interests of the shareholders.

Gervais and Odean (2001); Chang et al. (2009) show the existence of a positive relationship between optimism and uncertainty. This uncertainty implies the risk aversion and precisely the risk of the loss of the stability of position of CEO. So the leader will defend his interests and seeks to take a better position in society and refuses any decision that could change its current state. In this sense, the entry of new shareholders will increase the level of control exercised over the $\mathrm{CEO}$ which represents one of the dangers for this leader. This reflects the negative relationship between the CEO optimism level and the equity choice.

Debt carried out under the conditions described above can constitute a rooting strategy for the CEO. The strategy is for agents who wish to take root, to increase the cost of their replacement for their principal. By doing so, they can benefit from better job security, higher remuneration or even more freedom in their actions.

Faced with the many questions raised by research on the link between the optimism of leaders and the modes applied to control this cognitive bias, we will analyze the impact of certain governance mechanisms on the decisionmaking of financing by the biased agent. This analysis will focus on the internal mechanism of governance, the board of directors.

The board of directors is the central mechanism of the internal governance of the company. The relationship between executive optimism and the choice of board feature, as a key determinant of corporate governance, was founded by several previous researchers and particularly by Malmendier and Tate (2005). Implicitly, they suggest that corporate governance can be a solution for limited irrational management and especially those that derives from managerial optimism.

The board effectiveness is a few standards about its characteristics (Jensen, 1993) in what follows we develop the possible effect of the board mechanisms on leadership optimism and funding decision.

In this article, we try to develop some testable predictions in order to give some logical answers, even partial answer for the following question: Can manager optimism affect board efficiency and debt decision? This study aims to explore three main hypotheses that explain the effect of optimism on the board of directors characteristics (independence of members, duality and size) and the decision of indebtedness.

\section{Hypothesis Development}

Since the works of Modigliani and Miller (1958) who proved the irrelevance of financing decisions of companies under the conditions of the perfect market. A large number of theoretical and empirical analyzes have been developed to study the determinants of corporate finance decisions against real-world market imperfections. Earlier researchers in the field are generally two competing theories, the "Static Trade Off Theory" and the "Pecking Order Theory" which assume a great rationality. The study concludes that there is not a universal theory of capital structure choice while traditional explanations for capital structure largely repent on the rationality assumption of managers.

Some theorists have incorporated the behavioral dimension into the analysis of the choice of capital structure. They explain his choices by the emotions of the leaders. Malmendier and Tate (2005); Malmendier and Tate (2008) and Malmendier et al. (2010) formalize the notion of leadership behavior and provide empirical evidence to analyze the effects of biased CEOs on the preferences of financing and the choice of capital structure. In the Tunisian context, Azouzi and Jarboui (2012) analyze data from 100 firm and find a significantly positive correlation between optimism and the choice to apply internal financing (internally generated resources choice) while a negative 
relationship between optimism and the decision to increase capital. Parallel to the evolution of the capital structure theory new governance literature highlights CEO behavior and its impacts on different business decisions. Adam and $\mathrm{Li}$ (2012) state that the board is a moderator of behavioral biases among leaders. They add that the presence of the directors is justified by the forecasts of the valuations errors of the optimistic leaders. In other words, board independence is recommended to control the decisions of optimistic leaders. In this section, we examined the effect of the board's characteristics on the choice of debt by optimistic leaders.

\subsection{Managerial Optimism, Board of Director's Independency and Debt Choice}

Theorists point out that independent directors are an effective way of controlling the management team. Fama and Jensen (1983) suggest that the board is the best internal control mechanism to monitor management's behavior.

Baker et al. (2007) consider that the company's policies are appropriate for overvaluation and undervaluation of firms by market. External directors are aware that the market has undervalued their firms. They are reluctant to a new recourse to external funding mode. These directors help the optimistic manager (overstates the ability of his company) to make rational decisions. This implies a negative relationship between board independence and debt financing.

The presence of asymmetric information implies the increase in the cost of external financing methods (debt and equity choice). This encourages external director's members to minimize the use of its leader in external financing mode. This uninformed director aware of the bias of its leader seeks to limit the risk of the company by refusing the external financing mode (debt). This implies a negative correlation between the external directors and the firm debt ratio.

Schwizer (2013) shows that companies with the best economic performance in the list have independent members on the board. The author adds that the high level of performance is justified by the moderating effect of the board's independence on the behavioral biases of the manager at the evaluation of investment opportunities and risk decision. The presence of independent members reduces the manager's level of optimism and encourages him to make less risky decisions, including limiting the use of debt. Chang et al. (2012); Fauzi and Locke (2012) affirms this finding. The authors found that the level of indebtedness decreases in the presence of good governance signaled by a high level of independence.

Malmendier and Tate (2005); Malmendier and Tate (2008); Malmendier and Tate (2015) find that the optimistic manager will give priority to self-financing, then debt and ultimately to the issuance of shares. This preference for self-financing is justified by the presence of effective control. In fact, the presence of independent auditors obliges the manager to minimize the financial risk of his company by a weak recourse to the external modes of financing (debt choice and equity). This implies a negative correlation between the external directors and the firm debt ratio.

Ben-David et al. (2010) add that optimistic managers will tend to underestimate the volatility of their company's future cash flows or overweight their private signals relative to public information. This underestimation of risk prompts optimistic leaders to make a risky decision (the choice of debt). It is for this reason that shareholders require a high level of independence in the board of directors. Thus, the presence of a highly qualified director to assess the real risk of the company limits the biased decision (debt choice). This implies a negative correlation between the external directors and the firm debt ratio. It is in this context that the current work can be done, with an attempt to test the following hypothesis:

H1: Board of director's independency (low level of managerial optimism) is negatively correlated with firm debt ratios.

\subsection{Managerial Optimism, Board of Director's Size and Debt Choice}

Size is one of the most important features that can affect board efficiency. According to Jensen (1993) and Lipton and Lorsch (1992) a small board can perform its task properly. Thus, a small board limits the sub optimal decisions of an optimistic leaders whose rising debt level.

The board size has a significant impact in determining debt ratio. They concluded that the large board of directors, making firm more inclined to take risks and seek external financing resources. This is explained by the fact that the presence of a significant number of administrators implies the increase of the cognitive conflicts and reduces board effectiveness in the control of the leader. This optimistic leader of his company's capabilities is aware of weak control uses more risky decisions whose preference for debt.

Gervais et al. (2011) have shown that the capital part is the leader is a means of convergence of interests with these shareholders. The goal of a leader is to counter the control mechanisms, including the board of directors. In other words, an optimistic leader increases his share of capital to limit the effectiveness of small board and make risky decisions including the debt choice.

Jiraporn et al. (2012) find that firms whose managers are more entrenched (with large Board of directors) are significantly more leveraged. These authors then argue that debt and governance play the same role and may substitute for each other.This is also known by the optimism of the leader. Thus, an optimistic leader prefers indebtedness to signal his good management. Debt has a decisive role and becomes a perfect substitute of weak control of the board of director's. So a high level of debt is used by the optimistic CEO and the presence of a large Board.

Azouzi and Jarboui (2014) show that optimistic leaders overestimate the expected return on their projects. They use internal financing methods for the payment of dividends. They seek to make their shareholders more loyal and limit their control (small board). Consequently, they use the external mode of financing the least risky (debt) to concretize all the possible opportunities of the company. This asserts that even in the presence of an effective control (small board) the leader opts for the debt choice.

The increase in the number of board members to increase in the debt ratio.In other words, in large board there are problems of coordination, communication and decision-making. In this context the leader becomes freer in the management of the company. This optimistic and less controlled leader opts for risky decisions, including the debt 
choice. This implies a positive correlation between the board size and the firm debt ratio.It is in this context that the current work can be done, with an attempt to test the following hypothesis:

H2: An optimistic leader in a large board prefers more debt than a rational leader.

\subsection{Managerial Optimism, CEO Duality and Debt Choice}

CEO duality is defined as the occupation of the post of the executive manager and the chairman of the board of directors at the same time (Jensen, 1993). The association between the supervisory and management functions increases the leader optimism level. This optimistic leader will tend to invest in new projects. They are forced to choose debts because the presence of a strong asymmetry of information implies a higher premium demanded by the investors in case of an issue of new securities. The choice of debt is also intended to reduce the agency conflict between the optimistic leader and these shareholders.

Fairchild (2005) adds that the optimistic leader who believes he controls the risk of his business uses risky debt. The author shows that this leader makes arbitration between the probability of success of a project and its costs of funding. This arbitrage is affected by the ability to evaluate alternatives, including the optimism bias. In other words, the a dual function favor (CEO duality) increases the level of leader optimism. This bias impels him to take risky decisions including the preference for indebtedness.

Petra and Dorata (2008) study the link between the level of incentives and corporate governance structures. The authors conclude that the presence of duality CEO reduces the level of incentives. in other words, duality increases the leader's level of involvement and optimism. This optimistic leader has more motivation to work in the interests of these shareholders. They are aware that the sub market evaluates the value of their business. He has urged to issue debt securities to report the solvency of his business. He seeks to benefit from reports debt.

Abor (2007); Vakilifard et al. (2011) and Mokarami et al. (2012) argue that duality increases the manager's preferences for debt choice. Thus, duality reduces communication conflicts and favors the centralization of the decision. This decisional centralization facilitates the function of the leader. This context favors the emergence of optimistic leaders. These optimistic leaders seek to realize all the possible investment opportunities of their companies. They choose debt as a method of financing to avoid hostile public offers. Their objectives are to guarantee their places in the company.

Dufour and Molay (2010) postulate that the level of indebtedness of companies limits the risks of taking control. An optimistic (CEO duality) leader about the growth opportunities of the company with its interest to limit the risks of hostile acquisition. He uses a dual function to find a limited debt threshold, the risk of hostile acquisition and the good health of his business. It is in this context that the current work can be done, with an attempt to test the following hypothesis:

H3: CEO duality (high level of optimism) is positively correlated with firm debt ratios.

\section{Research Method}

\subsection{Data}

To note, the empirical tests are based on 75 non-financial Tunisian firms during the 2016 fiscal year (34 are listed companies and 41 are non-listed companies, see Table 1. All financial firms (including banks) outing to the fact that this business sector is regulated and likely to have fundamentally different cash flows and characteristics. Firms with insufficient data regarding about emotional characteristics and the board of director's composition are also excluded. The board's compositions, as well as financial characteristics data, are gathered from the BVMT annual report.

Emotional and psychological characteristics are collected by means of an administered questionnaire.

Table-1.Visited compagnie.

\begin{tabular}{l|c}
\hline Initial BVMT sample for 2016 & 81 \\
\hline Financial firms & $(25)$ \\
\hline Other non-financial firms & 49 \\
\hline Insufficient data to CEO emotional characteristics' & $(18)$ \\
\hline Insufficient data to board of directors compositions & $(12)$ \\
\hline Final sample & 75 \\
\hline
\end{tabular}

\subsection{Variables' Measurement}

The objective of this section is to determine the variables' measurement.

\subsubsection{Debt Level}

We observe several authors (Hovakimian et al., 2004) have selected a variety of variables that measure the level of debt in the company. Measures such as total debt service ratio. Other shave used the debt ratio in the medium and long term (Myers, 2001). The debt ratio in the short term was also used by Titman (1984). As part of our analysis we propose to use the debt ratio as a measure of this variable. It should be noted that this ratio is calculated by:

$$
\text { Leverage ratios }(\mathrm{LEV})=(\text { total debt } / \text { total assets }) \text {. }
$$

This measure is also used by Koh (2003); Demaria and Dufour (2007); Jarboui and Olivero (2008); Ben-David et al. (2010) and Sahut and Gharbi (2008); Azouzi and Jarboui (2012). To show that the manager uses debt or not, we can use the change in debt ratio. A positive change indicates the use of debt. Leverage ratios variation $=\mathrm{LEVN}-\mathrm{LEVN}-1 / \mathrm{LEVN}-1$ 
The questionnaire focuses on evaluating and scoring of the CEO optimism level the questions have been inspired from the questionnaires formulated by the Fern Hill and Industrial Alliance companies Table 2. The emotional bias takes two follows:

- 1 if the individual has a high level for optimism.

- 0 if not.

Table-2. Items used in the optimism scale (10 Items).

\begin{tabular}{|c|c|c|c|c|}
\hline Items & $\begin{array}{c}\text { Factor 1: } \\
\text { Estimate of } \\
\text { future returns } \\
25.17 \%\end{array}$ & $\begin{array}{c}\text { Factor } 2: \\
\text { Estimate of } \\
\text { growth } \\
\text { opportunities } \\
18.18 \%\end{array}$ & $\begin{array}{c}\text { Factor } 3: \\
\text { Ability to solve } \\
\text { problems } 13.75 \%\end{array}$ & $\begin{array}{c}\text { Factor } 4: \\
\text { Overestimation } \\
\text { of the personal } \\
\text { situation } \\
10.40 \%\end{array}$ \\
\hline $\begin{array}{l}\text { 1. Which of the following best describes } \\
\text { your financial goals? }\end{array}$ & 0.832514 & & & \\
\hline $\begin{array}{l}\text { 2.You are very comfortable with } \\
\text { investments that have the potential for } \\
\text { high returns even though they will } \\
\text { periodically drop in value }\end{array}$ & 0.773015 & & & \\
\hline $\begin{array}{l}\text { 3.My previous investments are always } \\
\text { successful thanks to my specific skills }\end{array}$ & 0.713358 & & & \\
\hline $\begin{array}{l}\text { 4.How do you see the next twelve } \\
\text { months? The general situation of your } \\
\text { company's }\end{array}$ & & 0.696078 & & \\
\hline $\begin{array}{l}\text { 5.I intend to increase my investments in } \\
\text { the next } 12 \text { months }\end{array}$ & & 0.808931 & & \\
\hline $\begin{array}{l}\text { 6.In times of uncertainty, I usually } \\
\text { expect the best }\end{array}$ & & 0.761058 & & \\
\hline 7. How do you see your profit forecasts? & & & 0.637175 & \\
\hline $\begin{array}{l}\text { 8. When something has pissed me off, I } \\
\text { can calm down quite quickly }\end{array}$ & & & 0.705453 & \\
\hline $\begin{array}{l}\text { 9. Your future seems more interesting } \\
\text { than your passing }\end{array}$ & & & & 0.636784 \\
\hline $\begin{array}{l}\text { 10. In my daily life, my emotions often } \\
\text { annoy me }\end{array}$ & & & & 0.815148 \\
\hline
\end{tabular}

\subsubsection{Board of Directors}

According to Fama and Jensen (1983) the board of directors must meet certain characteristics of independence, size and structure in order to fulfill its control role effectively.

\subsubsection{Board Size}

Noteworthy, the board's effectiveness highly depends on the number of directors and its size. Relevant literature provides no consensus about the direct relationship between the board size and effectiveness. On the one hand, a larger board is less likely to operate effectively and is easier for the CEO to control (Jensen, 1993). On the other hand, Yermack (1996) considers that the board size is a factor among a range of variables that might influence executive compensation and company performance.

In this study the directors' board size (BSIZE) has simply been measured by the number of its members (Dechow et al., 1996; Yermack, 1996; Pigé, 1998; Coulton et al., 2001).

\subsubsection{Board Independence}

The different characteristics pertaining to the board's independence are measured by the following variable: BIND is defined as the percentage of the board members who are simultaneously independent and non-executives which is equal to the number of outside directors divided by the total board members (Forker, 1992; Wright, 1996; Haniffa and Cooke, 2000; Coulton et al., 2001).

BIND $=$ number of outside directors / total board members

\subsubsection{CEO Duality}

Board chairs role consists in monitoring the CEO (Jensen, 1993). The latter supposes that CEOs who also hold the position of board chair (Duality) exert an undue influence on the board, compromising the strength of the board's governance. The board chairs characteristics are defined by DUAL $=1$ if the CEO also owns a board chair and 0 otherwise Table 3 presents the characteristics of boards of directors of the 75 Tunisian companies included in our study. Tunisian companies are run by independent boards, medium (seven directors) and not dominated by CEOs.

Table-3.Board of directors' characteristics.

\begin{tabular}{l|c|c|c|c|c}
\hline Variable & Mean & Std. & Min & Max & N \\
\hline Entire board & 9.50 & 3.20 & 4 & 12 & 75 \\
\hline Outside directors & 3.27 & 1.38 & 1 & 4 & 75 \\
\hline Affiliated directors & 2.47 & 1 & 1 & 3 & 75 \\
\hline Inside directors & 4.20 & 1.67 & 1 & 5 & 75 \\
\hline CEO Duality & 0.32 & 0.55 & 0 & 1 & 75 \\
\hline
\end{tabular}




\subsubsection{Control Variable}

\subsubsection{Ownership Concentration}

In our study, we will adopt the measure chosen Shabou (2000) adapted to Tunisian context. This variable is dichotomous; it is set to 1 (value 0 ) when the percentage held by the block holder is greater (less) than $50 \%$. The companies where the shareholders hold at least $50 \%$ of the capital were qualified as heavily concentrated.

\subsubsection{Firm Age}

In this study companies are divided into two groups, a business young and a mature company. This variable is dichotomous where a young firm refers to a company that operates less than five years old takes the value $O$ and a mature firm is greater than five years which takes the value 1 .

\subsubsection{Firm Size}

As noted by Ball and Foster (1982) size was used to represent the competitive advantage of a firm and the ability of the management team. So we can implicate size as a signal about the effectiveness of governance mechanisms. This is why we introduce size as a control variable for this research.

This variable can be measured in different ways. The size of the business can be measured in several ways, such as total assets, capital invested, turnover, number of employees, market value of business and equity.

We will retain the criterion of capital invested whose TAI variable is an ordered multinomial variable from which it takes 1 if the capital invested is less than 100 million dinars (Md), 2 if the capital invested is between 100 million dinars and 500 million dinars and 3 if the capital invested is more than 500 million dinars.

\subsubsection{CEO Seniority}

Seniority reflects the executive's experience expressed in years spent in the company. This variable may reflect the leader's experience, skills and relationship network. The leader's past can have a positive or negative effect on the degree of his optimism.

This variable is dichotomous (Pigé, 1998) it takes the value 0 for a new officer with a seniority of less than 5 years, and the value 1 for a CEO with seniority of more than 5 years.

\begin{tabular}{|c|c|c|c|c|c|}
\hline Class : & Phenomena : & \multicolumn{2}{|c|}{ Mesure : } & Variables : & Predictions : \\
\hline \multicolumn{6}{|c|}{ Endogens variables : } \\
\hline Debt Level & debt choice & \multicolumn{2}{|c|}{$\begin{array}{l}\text { Leverage ratios }(\mathrm{LEV})=(\text { total debt/ } \\
\text { totalassets }) \text { Leverage ratios variation } \\
=\mathrm{LEV}_{\mathrm{N}}-\mathrm{LEV}_{\mathrm{N}-1} / \mathrm{LEV}_{\mathrm{N}-1}\end{array}$} & \multicolumn{2}{|l|}{ LEV } \\
\hline \multicolumn{6}{|l|}{ Exogenous variables : } \\
\hline & & & & & LEV \\
\hline Optimism & $\begin{array}{l}\text { Directors } \\
\text { overestimate capacity } \\
\text { of their firms }\end{array}$ & \multicolumn{2}{|c|}{ The questionnaire obtained score } & OP & + \\
\hline \multirow[t]{3}{*}{$\begin{array}{l}\text { Board of } \\
\text { Directors }\end{array}$} & $\begin{array}{l}\text { Board implication in } \\
\text { the decision }\end{array}$ & \multicolumn{2}{|c|}{ Number of its members } & BSIZE & + \\
\hline & $\begin{array}{l}\text { The presence of } \\
\text { independent members } \\
\text { in the board }\end{array}$ & \multicolumn{2}{|c|}{$\begin{array}{l}\text { Number of outside } \\
\text { directors / total board members. }\end{array}$} & BIND & - \\
\hline & $\begin{array}{l}\text { CEO also owns the } \\
\text { board's chair }\end{array}$ & \multicolumn{2}{|c|}{$\begin{array}{l}1 \text { if the CEO also owns the board's } \\
\text { chair and } 0 \text { otherwise }\end{array}$} & DUAL & + \\
\hline \multicolumn{6}{|l|}{ Controls variables: } \\
\hline $\begin{array}{l}\text { Ownership } \\
\text { concentration }\end{array}$ & \multicolumn{2}{|l|}{ shareholder involvement } & $\begin{array}{l}1 \text { when the } \\
\text { percentage held by } \\
\text { the block holder is } \\
\text { greater than } 50 \% \\
\text { and o otherwise. }\end{array}$ & $\mathrm{OC}$ & + \\
\hline Firm Age & \multicolumn{2}{|l|}{ Firms signaled reputation } & $\begin{array}{l}1 \text { if firm is greater } \\
\text { than five years old } \\
\text { and o otherwise. }\end{array}$ & FIAGE & + \\
\hline Firm Size & \multicolumn{2}{|c|}{ Firms signaled performance } & $\begin{array}{l}1 \text { if the capital } \\
\text { invested is less than } \\
100 \text { million dinars } \\
(\mathrm{Md}), 2 \text { if the capital } \\
\text { invested is between } \\
100 \text { million dinars } \\
\text { and } 500 \text { million } \\
\text { dinars and } 3 \text { if the } \\
\text { capital invested is } \\
\text { more than } 500 \\
\text { million dinars. }\end{array}$ & FISIZE & + \\
\hline CEO Seniority & \multicolumn{2}{|l|}{ CEO signaled experience } & $\begin{array}{l}1 \text { if the CEO is at the } \\
\text { company more than } 5 \\
\text { years and } 0 \\
\text { otherwise. }\end{array}$ & SENI & + \\
\hline $\begin{array}{l}\text { CEO Financial } \\
\text { Education }\end{array}$ & \multicolumn{2}{|c|}{ Assessment of financial decisions } & $\begin{array}{l}1 \text { if the CEO to a } \\
\text { financial education } \\
\text { and o otherwise. }\end{array}$ & FIEDU & - \\
\hline
\end{tabular}




\subsubsection{CEO Financial Education}

This variable is dichotomous where a leader who has a financial education takes the value 1 and a manager who has gone through an education other than financial takes the value 0 .

For the purpose of simplification, we summarize the measurement of each of the model's variables, its name and its expected influence on the debt decision in the Table 4.

\section{Empirical Results}

We will check the relationship between managerial optimism, the board of directors and the debt decision using our model. In this costume, we describe in detail the different tests that are performed.

4.1. Empirical Model Where:

$$
\Upsilon=\alpha+\alpha_{1} O P+\alpha_{2} B S I Z E+\alpha_{s} B I N D+\alpha_{*} D U A L+\alpha_{5} O C+\alpha_{6} F I A G E+\alpha_{7} F S I Z E+\alpha_{s} S E N I+\alpha_{9} F I E D U+\xi .
$$

- $\quad$ : the firm debt choice (LEV).

- OP: the score of optimism.

- BSIZE: the board of director's size.

- BSIZE: the board of director's independence.

- DUAL: CEO duality.

- OC: the Ownership concentration.

- FIAGE: the firm age.

- FISIZE: the firm size.

- SENI: CEO seniority.

- FIEDU: CEO financial education.

\subsection{Empirical Tests}

We opted for the binary logistic regression on the various variables: This is to explain the effect of managerial optimism level on the involvement of the board of directors in the control of debt choice by appealing to the different variables selected.

\subsection{Results}

Table-5. Debt choice results

\begin{tabular}{|c|c|c|c|c|c|}
\hline \multicolumn{2}{|l|}{ Variables } & Bêta & Significance & $\begin{array}{c}\text { Expected } \\
\text { relationship }\end{array}$ & $\begin{array}{c}\text { Reached } \\
\text { relationship }\end{array}$ \\
\hline \multicolumn{2}{|l|}{ Constant } & 10.378 & 0.013278 & & \\
\hline \multirow[t]{4}{*}{ Optimism } & Future Returns Estimate & 1,233 & $0,022 * *$ & + & - \\
\hline & $\begin{array}{l}\text { Growth Opportunities } \\
\text { Estimate }\end{array}$ & 1,588 & $0,006 * * *$ & + & + \\
\hline & Ability To Solve Problems & 1,276 & $0,020 * *$ & + & + \\
\hline & Personal Situation Overestimation & 0,294 & 0,512 & + & + \\
\hline \multirow[t]{3}{*}{ Board of Directors } & BSIZE & $-5,099$ & $0,008 * * *$ & + & - \\
\hline & BIND & 5,867 & $0,003 * * *$ & + & + \\
\hline & DUAL & $-0,227$ & 0,825 & + & - \\
\hline \multicolumn{2}{|l|}{ FISIZE } & $-0,246$ & 0,764 & + & - \\
\hline \multicolumn{2}{|l|}{ FIAGE } & $-23,619$ & 0,999 & + & - \\
\hline \multicolumn{2}{|l|}{$\mathrm{OC}$} & 3,255 & $0,007 * * *$ & + & + \\
\hline \multicolumn{2}{|l|}{ SENI } & 26,332 & 0,998 & + & + \\
\hline \multicolumn{2}{|c|}{ FIEDU } & $-3,445$ & $0,003 * * *$ & - & - \\
\hline \multicolumn{3}{|c|}{ Cox and Snell ratios $\mathrm{R}^{2}$} & \multicolumn{3}{|l|}{0,476} \\
\hline \multicolumn{3}{|c|}{ Model $\mathbf{X}^{2}$} & \multirow{2}{*}{\multicolumn{3}{|c|}{45,524}} \\
\hline \multicolumn{3}{|l|}{-2 logs of likelihood } & & & \\
\hline \multicolumn{3}{|l|}{$\mathrm{N}$} & \multicolumn{3}{|l|}{75} \\
\hline
\end{tabular}

The results appearing on Table 5 show that managerial optimism and board characteristics explain $47.6 \%$ of the debt decisions of the companies in our sample, $\left(\mathrm{R}^{2}=47.6 \%\right)$.

The examination of the results concerning the variables related to managerial optimism shows a negative and significant relationship between the criterion of the estimation of future returns and the debt decision $(\beta=-1.233, p$ $=0.022)$. This can be explained by the fact that an optimistic executive who overestimates future returns applies less debt to minimize the financial cost and loyalty to these major shareholders. Overestimation of future returns implies a rise in the expected dividend level. The expected dividend increase leads to a valuation of the shares and favors the equity choice relative to the debt.

The results show the existence of a positive and significant relationship between the criterion of the estimation of growth opportunities and the decision of indebtedness $(\beta=1.588, \mathrm{p}=0.006)$. This implies that a optimistic CEO who is accustomed to overstating the investment opportunities of his company in times of uncertainty will increase his commitment to risky decisions (including the choice of debt). They are planning their ability to repay their debt. On the other hand, he believes that his company is undervalued by the market and avoids the equity choice. They therefore prefer debt. 
A positive and significant relationship in the range of $5 \%$ is between problem solving ability and debt level $(\beta=$ $1.276, \mathrm{p}=0.020)$. This relationship is explained by the fact that an optimistic leader overestimates his skills to reduce risks. This led him to choose riskier decisions, including the preference for additional debt choice.

The results also show a positive and insignificant relationship between the overestimation of the personal situation and the debt ratio. The non-significance of this criterion of optimism is justified by the vigilance of the agents. This is one of the rooting means is to ignore the personal situation in the work setting and in the strategic decisions making.

The results show a positive and significant relationship between the percentage of independent external directors on the board and the firms debt level $(\beta=5.867, p=0.003)$. The presence of independent directors gives the company the benefit of technical expertise and privileged environmental information in order to converge the interests of the principal with that of CEO. This convergence gives more freedom for the optimistic leader to increase the frequency of achievements of new projects. To finance these projects, optimistic leaders prefer debts to ignore the sharing of profits incurred on new shareholders in case of equity choice. This implies the increase in the debt level of the company. In other words, the existence of independent members on the board of directors gives a good signal on the leading part of the company. The latter seems to have a favorable and easier access to debt.

We also note that the debt level is in negative relation and not significant with the CEO duality $(\beta=-0.227, p$ $=0.825)$. This is justified by two factors, debt and the nature of Tunisian firm. In fact, if a company is in debt, it is subject to the power of an external auditor who does not accept the presence of a CEO as chairman of the board.On the other hand, there is a large percentage of family businesses in Tunisian companies. This negatively affects the significance and robustness of responses (72\% of companies are family businesses).

The regression also shows a negative and significant relationship between board size and debt ratio $(\beta=-$ 5.099, $\mathrm{p}=0.008)$. A plausible justification for this result is that an optimistic manager who seeks to increase the value of the company prefers to have greater discretion over his future investments. Indeed a small board of directors can keep this discretion. His asymmetry leads to undervaluation of the new securities issued. As a result, the choice of financing through equity choice will be more expensive. So a little advice will encourage debt choice.

There is a positive and significant relationship between indebtedness and ownership structure of the firm $(\beta=$ $3.255, \mathrm{p}=0.007)$. The presence of block holders is considered a disciplinary governance mechanism associated with a high level of control over the leader. Thus, the strict control and discipline exercised by the block holders helps to align the manager's behavior with the company's objectives and limit his discretionary attitude. An optimistic leader is aware of the risk of losing his job and reputation on the market. He seeks to signal his good management by a preference for debt.

There is evidence of a negative and insignificant relationship between firm size and debt level $(\beta=-0.246 \mathrm{p}=$ 0.674).Due to better investor knowledge, large companies can issue securities more easily without being undervalued than small businesses.

Another interesting result is that the age of the company can increase the debt ratio $(\beta=-23,619, p=0.999)$. This is justified by the fact that mature firms have more experience with the adverse effects of debt. They are therefore more attentive in their preferences for debt.

The correlation between the debt ratio and CEO seniority is positive and not significant $(\beta=26.332, \mathrm{p}=$ 0.998).The seniority of the leader leads him to maintain relations with the market. These contacts lead to strong links with the lenders so the use of debt as a means of financing will be easier.

Finally our results indicate a negative and significant correlation between the CEO financial education and firm debt level $(-3,445,0.003)$. The financial education of the leader leads him to make rational financial decisions including the choice of a low level of debt. This manager is more aware of the risk of bankruptcy of the company in the case of a high level of debt. Financial education therefore reduces the negative effects of optimism and psychological bias on managerial decisions.

\section{Conclusion}

In this article, we have advanced an original essay that aims to discuss the effect of managerial optimism and board characteristics on the on funding preferences and capital structure choice.Starting from the role of the introduction of the behavioral dimension in the enrichment of the analyzes of corporate governance and capital structure, we aim to note the effects of optimism bias on the decisions of senior managers in Tunisia companies, this work has attempted to achieve the following objectives:

- Present the notion of managerial optimism and its integration into the theory of corporate governance and the theory of capital structure.

- Studying the impact that executive optimism would have, directly or indirectly, on board control effectiveness and consequently on the debt decision.

- Verify the presence of a relationship between the optimism bias of the leader, the board of directors and the debt level.

The theoretical analysis presented argues in favor of the direct impact of CEO optimism on the effectiveness of control exercised by the board of directors and subsequently on the debt decision. Even more we have presented other actors who can affect the bias of optimism and the decision of indebtedness. These actors are the characteristics of the company (size and age) and the characteristics of the leader (seniority and education).

The empirical part attempted to fill a deficit in research in behavioral finance, by presenting a survey on the executives of large private companies in Tunisia. The analyzes of the data collected revealed the importance of leadership optimism in the debt decision. The empirical analysis of the relationship of managerial optimism with the board of directors (size of board, presence of external and cumulative functions) and the decision of financing by debt shows different results. In general, there is a positive impact of managerial optimism on the level of debt of Tunisian companies. Our analyzes revealed the importance of CEO optimism in the debt decision.It has been found that an optimistic leader prefers more debt even in companies ruled by independent boards.On the other hand, the results analyzing the hypotheses 2 and 3 regarding the size of the board and the combination of CEO and Board 
Chair does not confirm our theoretical analysis. This affirms the complementary relationship between our three notions.

Our research is only an attempt to focus the spotlight on the effects of the behavior of executives of Tunisian companies on the efficiency of board control and on the choice of means of financing. So it is necessary to present the following recommendations to Tunisian companies:

- Apply psychological tests instead psycho-technical tests in the selection of frames to detect behavioral kicks.

- Implementation of emotional intelligence training programs designed to give the leader the ability to understand and control his emotions.

\section{References}

Abor, J., 2007. Corporate governance and financing decisions of Ghanaian listed firms corporate governance: The international Journal of Business in Society, 7(1): 83-92.Available at: https://doi.org/10.1108/14720700710727131.

Adam and $\mathrm{Li}, 2012$. The new corporate directors. New York: John Wiley and Sons.

Azouzi, M.A. and A. Jarboui, 2012. CEO emotional bias and capital structure choice. Bayesian network method. Business Excellence and Management, 2(2): 47-70.

Azouzi, M.A. and A. Jarboui, 2014. CEO emotional intelligence and firms' financial policies. Bayesian network method. Contemporary Economics, 8(1): 5-24.Available at: https://doi.org/10.5709/ce.1897-9254.128.

Azouzi, M.A. and A. Jarboui, 2018. CEO's emotional commitment level and its firm capital structure choice: Decision tree analysis. Asian Journal of Economics and Empirical Research, 5(1): 65-78.Available at: https://doi.org/10.20448/journal.501.2018.51.65.78.

Baker, M., S.R. Richard and J. Wurgler, 2007. Behavioral corporate finance. The Handbook of Corporate Finance, 1: 145-186.Available at: https://doi.org/10.1016/B978-0-444-53265-7.50018-4.

Ball, R. and G. Foster, 1982. Corporate financial reporting: A methodological review of empirical research. Journal of Accounting Research, 20: 161-234.Available at: https://doi.org/10.2307/2674682.

Ben-David, I., J.R. Graham and C.R. Harvey, 2010. Managerial miscalibration, SSRN Working Paper. Electronic Copy. Available from http://ssm.com/abstract $=1640552$.

Chang, C., A.C. Lee and C.F. Lee, 2009. Determinants of capital structure choice: A structural equation modeling approach. The Quarterly Review of Economics and Finance, 49(2): 197-2 13.Available at: https://doi.org/10.1016/j.qref.2008.03.004.

Chang, K.H., L.-H. Wang and H.-W. Liu, 2012. Corporate governance and capital structure: Evidence from Taiwan SMEs. Review of Economics \& Finance, 2: 43-58.

Coulton, J.J., C. James and S.L. Taylor, 2001. The effect of compensation design and corporate governance on the transparency of CEO compensation disclosures. Finance Control Strategies, 1(2): 57-88.

Dechow, P.M., R.G. Sloan and A.P. Sweeney, 1996. Causes and consequences of earnings manipulation: An analysis of firms subject to enforcement actions by the SEC. Contemporary Accounting Research, 13(1): 1-36.Available at: https://doi.org/10.1111/j.19113846.1996.tbo0489.x.

Demaria, S. and D. Dufour, 2007. Les choix d'options comptables lors de la transition aux normes IAS/IFRS: Quel rôle pour la prudence? Comptabilité-Contrôle-Audit, 13(3): 195-218.Available at: https://doi.org/10.3917/cca.133.0195.

Dufour, D. and E. Molay, 2010. The financial structure of French SMEs: A sectorial analysis on panel data. Author's manuscript, published in crises and problematic news of value, Nice, Hal-00479529, version 1, new issues of value. Nice: 31 st Congress of the Francophone Accounting Association 2010. pp: 1-18.

Fairchild, R., 2005. The effect of managerial overconfidence, asymmetric information, and moral hazard on capital structure decision. ICFAI J Behav Finance, $2(4): 46-68$

Fama, E.F. and M.C. Jensen, 1983. Agency problems and residual claims. The Journal of Law and Economics, 26(2): 327-349.Available at: https://doi.org/10.1086/467038.

Fama, E.F. and M.C. Jensen, 1983. Separation of ownership and control. The Journal of Law and Economics, 26(2): 301-325.

Fauzi, F. and S. Locke, 2012. Board structure, ownership structure and firm performance: A study of New Zealand listed-firms. Asian Academy of Management Journal of Accounting of Finance, 8(2): 43-67.

Forker, J.J., 1992. Corporate governance and disclosure quality. Accounting and Business Research, 22(86): 111-124.

Frank, M.Z. and V.K. Goyal, 2003. Testing the pecking order theory of capital structure. Journal of Financial Economics, 67(2): 217248.Available at: https://doi.org/10.1016/s0304-405x(02)00252-0.

Gervais, S., J.B. Heaton and T. Odean, 2011. Overconfidence, compensation contracts, and capital budgeting. The Journal of Finance, 66(5): 1735-1777.Available at: https://doi.org/10.1111/j.1540-6261.2011.01686.x.

Gervais, S. and T. Odean, 2001. Learning to be overconfident. The Review of Financial Studies, 14(1): 1-27.Available at: https://doi.org/10.1093/rfs/14.1.1.

Haniffa, R. and T. Cooke, 2000. Culture, corporate governance and disclosure in Malaysian corporations. Asian AAA World Conference, Singapore.

Heaton, J., 2002. Managerial optimism and corporate finance. Financial Management, 31(2): 33-45.

Hovakimian, A., G. Hovakimian and H. Tehranian, 2004. Determinants of target capital structure: The case of dual debt and equity issues. Journal of Financial Economics, 7 1(3): 517-540.Available at: https://doi.org/10.1016/s0304-405x(03)00181-8.

Jarboui, A. and B. Olivero, 2008. Is the risk / time horizon of the investments pair governed by the institutional and the dominant shareholders? [The Risk / Investment Time Horizon is governed by the institutional and controlling shareholders?]. Bank and Markets, 93(1): 20-34.

Jensen, M.C., 1993. The modern industrial revolution, exit, and the failure of internal control systems. Journal of Finance, 48: 831880.Available at: https://doi.org/10.1111/j.1540-6261.1993.tb04022.x.

Jiraporn, P., J.-C. Kim, Y.S. Kim and P. Kitsabunnarat, 2012. Capital structure and corporate governance quality: Evidence from the institutional shareholder services (ISS). International Review of Economics \& Finance, 22(1): 208-22 1.

Koh, P.-S., 2003. On the association between institutional ownership and aggressive corporate earnings management in Australia. The British Accounting Review, 35(2): 105-128.Available at: https://doi.org/10.1016/s0890-8389(03)00014-3.

Lipton, M. and J.W. Lorsch, 1992. A modest proposal for improved corporate governance. The Business Lawyer: 59-77.Available at: https://doi.org/10.1007/978-1-349-14158-6_3.

Malmendier, U. and G. Tate, 2005. CEO overconfidence and corporate investment. Journal of Finance, 60(6): $2661-2700$.

Malmendier, U. and G. Tate, 2008. Who makes acquisitions? CEO overconfidence and the market's reaction. Journal of Financial Economics, 89(1): 20-43.Available at: https://doi.org/10.1016/j.jfineco.2007.07.002.

Malmendier, U. and G. Tate, 2015. Behavioral CEOs: The role of managerial overconfidence. Journal of Economic Perspectives, 29(4): 3760.Available at: https://doi.org/10.1257/jep.29.4.37.

Malmendier, U., G. Tate and J. Yan, 2010. Managerial beliefs and corporate financial policies. Working Paper, $n^{\circ} 105$, UC Berkeley and UC Los Angeles, Faculty.fuqua.duke.edu.

Modigliani, F. and M.H. Miller, 1958. The cost of capital, corporation finance and the theory of investment. The American Economic Review, 48(3): 261-297.

Mokarami, M., M.R. Ahmadi and A.H. Hosseinzadeh, 2012. Corporate governance and financial decision making in the firms listed on Tehran stock exchange. International Research Journal of Finance and Economics, 93: 164-171.

Myers, S.C., 2001. Capital structure. Journal of Economic Perspectives, 15(2): 81-102.

Petra, S. and T.N. Dorata, 2008. Corporate governance and chief executive officer compensation. Corporate Governance, 8(2): 141152.Available at: https://doi.org/10.1108/14720700810863779. 
Pigé, B., 1998. Enrichment ten dragons or recharges with ten octaneoires. Finance Contrôle Stratégie, 1(3): 131-158.

Sahut, J. and O. Gharbi, 2008. Institutional investors and typology and firm performance: The case of French firms. International Journal of Business, 15(1): 34-48.

Schrand, C. and S. Zechman, 2010. Executive overconfidence and the slippery slope to fraud. Journal of Accounting and Economics, 53(1-2): 311-321.

Schwizer, P., 2013. A resolute: The creator of Christendom's heart system by the controlled internet. In Internal Governance - New rules, Experiences, Best Practices For the organization of internal controls of banks, edited by Paola Schwizer. Milan: Egea. pp: 87 - 118.

Shabou, R., 2000. Nature of control block holders, control mechanisms and financial performance of Tunisian companies [Nature of holders of control blocks, control mechanisms and Financial performance of Tunisian companies]. Working Paper. University of Sfax. Gestion 2000 6, (2003).

Titman, S., 1984. The effect of capital structure on a firm's liquidation decision. Journal of Financial Economics, 13(1): 137-151.Available at: https://doi.org/10.1016/0304-405x(84)90035-7.

Vakilifard, H.R., M.S. Gerayli, A.M. Yanesari and A.R. Ma'atoofi, 2011. Effect of corporate governance on capital structure: Case of the Iranian listed firms. European Journal of Economics, Finance and Administrative Sciences, 35: 165-172.

Wright, D.W., 1996. Evidence on the relation between corporate governance characteristics and the quality of financial reporting. Working Paper, University of Michigan School of Business Administration. Research Support); -- no. 9601-18. Handle. Available from http://hdl.handle.net/2027.42/36268.

Yermack, D., 1996. Higher market valuation of companies with a small board of directors. Journal of Financial Economics, 40(2): 185211.Available at: https://doi.org/10.1016/0304-405x(95)00844-5. 